\title{
ADOÇÃO. INDISPENSABILIDADE DO EXAME DE TODOS OS ELEMENTOS EM FAVOR DO FUTURO E DA FELICIDADE DA CRIANÇA
}

\author{
Antonio Chaves \\ Professor Catedrático aposentado da Faculdade de Direito da Universidade de São Paulo
}

Resumo:

A adoção posiciona no centro das atenções a criança em situação de abandono, na procura do direito da criança a possuir uma família, caducando a idéia do passado que tinha como fulcro principal o interesse do adulto em ter um filho. A matéria versa, ainda, os dilemas éticos cada vez mais confusos, como os de quem tem mais direito: os pais adotivos ou os naturais.

\begin{abstract}
:
The adoption makes salient the bereaved children, when searching their right for a family, declining the old idea wich had as main support the interest of the adult in giving birth to children. The subject also treats of ethical dilemmas more and more confused, for example, who should be entitled to the child's guard: the foster or the biological parents.
\end{abstract}

Unitermos: adoção; guarda provisória; pais adotivos e naturais.

Os distintos colegas, advogados Drs. Bertolino Luiz da Silva e Ângela Cecília César Zamberlan, ela também engenheira, casados e residentes em Mairiporã, SP, viram-se, em seu trabalhoso pedido de adoção número 24/95, promovido pela Comarca de José Bonifácio, aos 22 de fevereiro do corrente ano de 1995, da criança então recém-nascida, Luis Roberto Batista, após terem obtido sua guarda provisória, declarados por sentença de 20 de junho, do Juiz de Direito José Walter Chacon Cardoso "carecedores da ação" e "extinto, sem julgamento de mérito e com fulcro no art. 267, inciso IV. do Código de Processo Civil" o pedido, revogada a guarda provisória, determinando a entrega do mesmo ao pai biológico, Levi Teodoro do Prado.

Tomados de surpresa, ante esse sumário e inopinado desfecho do processo, sem que tivesse sido sequer iniciada a instrução, e em verdadeiro estado de choque, devido à afeição que nutrem pela inocente criatura, solicitam-me parecer, 
formulando quatro quesitos que passo a reproduzir, para acompanhá-los das considerações pertinentes e respectivas respostas:

1. $O$ destino de um recém-nascido entregue em adoção não pode ser sopesado e decidido a não ser depois de uma avaliação completa de todos os elementos e provas possiveis.

Primeiro quesito: sem embargo das boas intenções, não foi precipitado o M. Juiz ao estancar tão sumariamente o curso do processo, impedindo não só os consulentes, como o Ministério Público e também a parte adversa que havia solicitado a fl. $125 \mathrm{v}$. prova oral, depoimento de Elisete Batista Rodrigues $e$ testemunhas a serem arroladas oportunamente?

Seja-nos permitido iniciar estas considerações abrigando-as sob o conceito fundamental de Vieira: "O filho por natureza ama-se porque é filho; o filho por adoção é filho porque se ama".

É a idéia que deveria servir como ponto de partida para qualquer consideração em toda matéria que envolve, de um lado, o pai ou a mãe pelo sangue, que entregou uma criança recém-nascida a outrem: este ato comprova ou não ter existido este amor por ter dado origem ao filho, ou, se existiu, deixou-se sobrepujar pela acomodação ou pelo reconhecimento, aliás nobilitante, de não se encontrarem em condições de criá-la convenientemente.

Em nosso Adoção, Belo Horizonte, Del Rey, $5^{\mathbf{a}}$ ed., 1995, esclarecemos, à p. 28, que o antigo "preconceito daqueles que insistem em que a adoção não passaria de um meio concedido ao adotante para inserir um elemento estranho a fim de continuar a série familiar" passou para segundo plano, atendendose hoje em dia à conveniência não apenas do adotante, mas, principalmente, do adotado.

Percebeu-o claramente, Osvaldo Leite de Moraes: a finalidade mais importante da adoção em nossos dias é a proteção dos menores.

Não é outro o resultado de uma minuciosa investigação a que procedeu Marc Ancel, que, contando com a colaboração de 52 especialistas internacionais, pôde afirmar que " $L$ ' adoption moderne, au contraire" da adoção tradicional, "est conçue désormais dans l'intérêt de l'adopté, objet principal et 

e da felicidade da criança

bénéficiaire de la réglementation nouvelle" ( $L^{\prime}$ adoption dans les legislations modernes).

Aditamos à p. 29 afinarem-se pelo mesmo diapasão as idéias de Levi Carneiro, mostrando que a adoção vai perdendo o feitio meramente afetivo e sentimental, caracterizando-se como medida de assistência, sob a fiscalização da autoridade pública.

E concluímos com o Desembargador José Benício de Paiva: "houve uma inversão de conceitos. Não se funda mais no interesse privado, recobra um altíssimo fim político-social. Despiu-se dos seus caracteres clássicos, daqueles que lhe deram vida na legislação romana (...) A situação social da vida contemporânea faz a adoção ressurgir do passado com outras finalidades que lhe propiciam larga projeção na legislação do futuro."

Será uma solução acomodatícia, mas nem social, nem jurídica, ceder ao apelo fácil da "voz do sangue", tantas vezes em tal surdina que nem o mais aguçado ouvido é capaz de distinguir.

Por isso mesmo, longe de acolher o primeiro requisito do revogado Código de Menores, que no art. 27 colocava o infante para que pudesse ser adotado sob a condição de encontrar-se em situação irregular, partindo para princípio oposto não formula tal exigência o Estatuto da Criança e do Adolescente, admitindo seja adotado independentemente de sua situação jurídica, como deixa claro o art. 28, que, com os arts. 29 a 32, regulam a colocação em família substituta.

A mesma solução fria, formalista, da sentença do M. Juiz de Direito de José Bonifácio deu seu colega da comarca de Coxim, do Estado de Mato Grosso do Sul, ao pedido de Eulice Jacinta Xavier Guimarães, que havia recebido o menor Mário Márcio da Silva, que pretendia adotar, do pai dele, quando o menor tinha três meses de idade e pouco depois da morte de sua mãe.

Deu razão a ela, no entanto, o Tribunal de Justiça, pela sua Turma Cível, por votação unânime em 8 de maio de 1986. Ressaltou o relator, Des. Leão Neto do Carmo que, no caso, tudo aconselhava a adoção pela requerente. Verbera o julgador $a$ quo, que, opondo-se à advertência do nosso codificador civil, que se exprime nas palavras citadas por Antônio Chaves, em Adoção e Legitimação Adotiva, (RT, 1966, pp. 5 e 6), esqueceu-se que a família, o conforto, estímulo e consideração já foram dados ao menor, cujo futuro a requerente quer, com a adoção, em mais um gesto de nobilitante despreendimento, assegurar ou facilitar, negou o pedido apegando-se a formalismo que não se ampara na lei. 
Pertinentes, pois, data venia, as observações do juiz paulista Milton Gordo, transcritas no Informativo Semanal ADV. n. 24, de 16 de junho do corrente ano de 1995: em sua antecipação do julgamento, sem ter dado oportunidade ao casal adotante de produzir as provas indispensáveis e sem ter sequer ouvido a assistente social, que iria verificar em que lar a criança estaria melhor situada:

"A isenção, a imparcialidade no julgamento, é atributo do julgador, do qual não se pode despojar, a pretexto de reajustar desequilíbrios sociais. Isso não quer dizer que não seja sensível aos reclamos dos menos favorecidos. Como homem do povo, essa sensibilidade deve estar sempre presente no julgador, mas não ao ponto de ignorar a norma legal e utilizar uma própria, porque assim estará, na sua óptica, melhor realizando a justiça. Daí porque cuidará sempre de observar a lei e dela extrair a interpretação que traduza esse sentido de justiça social."

2. A melhor solução é a determinada pelo Estatuto da Criança e do Adolescente: romperem-se, com a adoção, os no caso, muito precários vínculos com a mãe e com o não bem definido pai do adotando.

Segundo quesito. Deferir, tão-sumariamente, displicente pedido, em três linhas, sem fundamentação, de entrega "desde já do menor ao pai", não atenta contra a elementar cautela de possibilitar mais concreta fundamentação, o fato de não ter proporcionado uma oportunidade de minucioso exame, por meio de assistentes sociais, das condições em que ficaria a criança junto a uns e outros pretendentes?

"Quem continua encarando o instituto da adoção apenas sob o ponto de vista do interesse do adotante ou dos pais do adotando"- consignamos à p. 353 de nosso Adoção, "admitirá a invalidade do ato pelo ulterior reconhecimento."

Quem, todavia, atentar para as superiores vantagens do adotando, não deixará de convir em que o reconhecimento tardio, quando o menor já se encontra abrigado e protegido, ambientado e cercado de afeto em seu novo lar, jamais poderá 
ter o alcance de retirá-lo dessa situação confortadora, para colocá-lo à mercê de pais retardatários no cumprimento, já agora suspeito, do mais elementar dos seus deveres.

A autoridade Judiciária deverá" note-se bem a força dessa expressão, que é uma exigência, não um simples aconselhamento "determinar a realização de diligências especiais, através de equipe interdisciplinar prevista nos arts. 150 e 151 da Lei n. 8.069/90" teve a oportunidade de encarecer Tânia da Silva Pereira. A adoção no Brasil, após a Constituição Federal de 1988 e as novas perspectivas legais para a adoção internacional, na Revista da Faculdade de Direito da Universidade do Estado do Rio de Janeiro, n. 2, 1994, p. 421 "a qual confirmará a situação social e idoneidade moral do adotante, além de sua saúde física, psíquica e sua educação. A situação econômica se provará com o comprovante dos ganhos, com a declaração de renda, onde constarão os bens."

"Com a adoção"- acrescenta linhas adiante "são rompidos os vínculos com os pais e parentes da família biológica, com exceção dos impedimentos matrimoniais (art. 41, 1º ECA); não se restabelece o Pátrio Poder dos pais biológicos nem mesmo com a morte dos adotantes (art. 49, ECA)."

Ocupamos às pp. 378 usque 383, que pedimos venia para considerar aqui incorporadas, do referido "Adoção", encarecendo a indispensabilidade de diligências e sindicâncias, objetivando a comprovação da conveniência do menor, o seu futuro e bem-estar, transcrevendo a pregação do grande especialista francês, Raphael Velionski, La Légitimation Adoptive, Enseignement et Perfectionnement Techniques, nos idos de 1954, considerando necessário, mediante textos apropriados, ou, ao menos, por um inquérito seriamente conduzido por pessoas competentes, esclarecer os adotantes e, principalmente, elucidar o juiz. A lei deveria prever e impor este exame: evitaria muitas frustrações e infortúnios, que fazem tantas vezes a infelicidade da criança.

Transcrevemos o disposto no art. 57 do Código de Família soviético:

"A adoção só é permitida com relação às crianças e menores, e exclusivamente no interesse das crianças" 
E do art. 343 do Código Civil francês:

"A adoção não pode ter lugar a não ser que haja justos motivos e que apresente vantagens para o adotado"

À p. 381 reproduzimos o texto do art. $5^{\circ}, \S 1^{\circ}$ da revogada Lei $n$. 4.655 ordenando ao juiz, tendo em vista as conveniências do menor, o seu futuro e bem-estar, proceda de ofício ou a requerimento do Ministério Público as diligências e sindicâncias que julgar necessárias.

E o Provimento n. LI, de 04 de fevereiro de 1957 do Conselho da Magistratura do Estado de São Paulo, recomendando que o menor, quando possível, seja "encaminhado à respectiva equipe médico-social, composta de médico, psicologista e assistente social, no mínimo. Onde não houver dessas equipes, será o menor submetido a exame médico e de escolaridade, procedendo-se ainda à coleta de dados sobre sua situação social, moral e econômica, bem como a de sua família, em ordem a poder o juiz, com segurança, orientar-se a respeito do destino provisório a ser-lhe dado, bem como das providências cautelares que o caso esteja a exigir..."

E em nosso Comentários ao Estatuto da Criança e do Adolescente, S.Paulo, LTR, 1994, transcrevemos o preceito do art. 227 da Constituição Federal, assegurando-lhes os direitos primordiais, com absoluta prioridade, entre os quais à profissionalização, à cultura, etc., colocando-os a salvo de toda forma de negligência, discriminação, etc.

Bem como acórdão unânime do TJSP, por sua Câmara Especial, de 08 de agosto de 1991, verdadeiro farol a iluminar casos de duvidosa solução, como ocorreu:

"Desta norma áurea há que concluir, em primeiro lugar, que no conflito entre direitos, têm primazia os direitos da criança e do adolescente. Em seguida, que a Constituição, sem estar desatenta às necessidades materiais da vida, valoriza devidamente os seus aspectos espirituais, como a educação, a cultura, a dignidade, o respeito. E que procura defendê-los de qualquer forma de manipulação desumana, intencional ou não." 
No trato de matéria de tão alto interesse humano e social, no estabelecimento de precedentes que fatalmente hão de ter repetições, não é possível deixar de lado a admoestação de George Ripert, Revolta dos fatos contra a Lei:

..."as regras gerais têm caráter eminente se se puder demonstrar que elas são exigidas pela razão humana.

Seu valor será, então, tal que se tornará impossível admitir que uma lei possa desrespeitar um princípio, porque isso seria o mesmo que dizer que ela é contrária à razão.

Ela seria, por outro lado, inaplicável, porque o espírito humano jamais poderia aceitar as conseqüências extravagantes que dela resultariam.

Chega-se, assim, à noção dos princípios racionais, que constituem um obstáculo ao poder do legislador."

(Les Forces Créatives du Droit, Lib. Gen. de Droit, Paris, 1955, p. 332)

Existe, todavia, mais um fundamento relevante que anima os requerentes em sua pretensão, o que faz parte dos procedimentos de Jurisdição Voluntária, também chamada de Administração Pública de Interesses Privados. Embora não arrolados no Cap. I do Título II do Código de Processo Civil, é poder conferido pelo Estado ao magistrado para intervir na seara privada em assuntos considerados da mais alta relevância relativos a interesses particulares em que não existem conflitos.

É justamente circunstância posta em relevo na monografia do saudoso Professor e Ministro Moacyr Amaral Santos, Primeiras Linhas de Direito

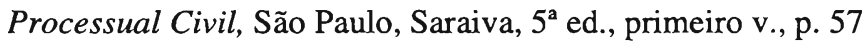

..."não há pedido de uma parte contra ou em relação a outra, isto é, não há duas partes, autor e réu, mas apenas interessados."

Assim, teve oportunidade de encarecer em magnífica sentença de 47 laudas, datada de 21 de fevereiro de 1991 (não divulgada), o Juiz de Direito de Mangaratiba, RJ, Marco Antonio Ibrahim, Proc. n. 3.684/90: 
"... nestes procedimentos, a apreciação dos pedidos não fica vinculada, rigidamente à Lei. Quis o legislador (como a minorar os efeitos da intervenção estatal na vida do cidadão) que em tais procedimentos pudesse o juiz julgar consoante lhe parecesse mais justo, porque não é novidade que nem sempre aquilo que é legal, é justo. Com efeito reza o art. 1.109 do C.P.C., inspirado no art. 1.410 do CPC de Portugal:

" O Juiz decidirá o pedido no prazo de dez dias; não é porém obrigado a observar o critério da legalidade estrita, podendo adotar em cada caso a solução que reputar mais conveniente ou oportuna".

Transcreve, entre outras considerações, o magistério de José Alberto dos Reis, comentando o referido Código Português, em obra póstuma:

"Um julgamento pode inspirar-se em duas orientações ou dois critérios diferentes: critério de legalidade, critério da eqüidade. No primeiro caso, o Juiz tem de aplicar aos fatos da causa o direito constituído; tem de julgar segundo as normas jurídicas que se ajustam à espécie respectiva, ainda que, em sua consciência, entenda que a verdadeira justiça exigiria outra solução.

No segundo caso, o julgador não está vinculado à observância rigorosa do direito aplicável à espécie vertente; tem a liberdade de se subtrair a esse enquadramento rígido $e$ de proferir a decisão que lhe pareça mais eqüitativa.

Quer dizer, o Juiz funciona como árbitro, ao qual fosse conferido o poder de julgar ex aequo et bono" (Processos Especiais, v. II, 1956, p. 400 - apud José Olympio C. Filho). 
No mesmo sentido Manoel A. Domingues de Andrade, também citado pelo referido autor indica no seu Noções Elementares de Processo Civil (1963, p. 72) que um dos princípios fundamentais a ser aplicado aos procedimentos de Jurisdição Voluntária é o "Predomínio da Eqüidade sobre a Legalidade".

3. Razões da imprescindibilidade da oitiva de assistentes sociais

"Terre des Hommes" entidade sediada em Lausanne, Suíça, fundada em 1960 e autorizada a desenvolver suas atividades no Brasil pelo Decreto n. 95.960, de 25 de abril de 1988, publicada já há oito anos, graças à diligência do seu representante no Brasil, Dr. Fernando Freire, um boletim mensal, que, em reiterados números de exemplares, tem insistido em que "é muito recomendável"- como diz trecho extraído do Manual de Procedimentos para a Formação da Família Adotiva, Francisco J. Pilotti, Instituto Interamericano da Criança, Montevidéu, no de n. 29, de setembro de 1991 "que na formação da família adotiva intervenha uma equipe interdisciplinar qualificada, realizando suas atividades em um limite institucional devidamente reconhecido e regulamentado.

No exemplar de n. 31, de novembro desse mesmo ano de 1991, a Assistente Social Elena Allegri, escrevendo sobre $O$ Papel do Serviço Social na Adoção encarece a necessidade de "observar como se desenvolve o trabalho social, que deve reconhecer e recolher dados da realidade da criança, informações, fatos, descrições de circunstâncias concretas, com base nas quais o juiz será chamado a decidir. Se trata de fornecer dados objetivos sobre a escolaridade, sobre a habitação, sobre o trabalho, para fornecer uma imagem do ambiente social $e$ familiar. É necessário refletir sobre o conceito de objetividade."

Em um relatório social, são relacionados fatos objetivos, e eles não são, e não podem ser separados do pensamento e da opinião, da interpretação dos fatos.

(...)

No nosso trabalho, o tempo efetivo da criança se encontra com o tempo administrativo e o tempo da máquina judiciária por vezes úteis para decisões muito delicadas, por vezes motivo de futuros sofrimentos.

Existem algumas condições indispensáveis para evitar perigosos mecanismos perversos que podem nascer quando existe a confusão. Quem se dirige aos 
nossos serviços é portador de um sofrimento, e tem direito de ser respeitado em seu sofrimento. Tem direito de encontrar um técnico formado, atento, competente $e$ sensivel.

\section{(...)}

A sistematização das relações entre a comunidade $e$ autoridade judiciária é um outro ponto crucial. É necessário superar o relacionamento exclusivo entre $o$ técnico e o juiz, e encontrar um terreno fértil de entendimento.

Exemplar n. 32, dezembro de 1991, a mesma Elena Allegri:

"A revolução no campo da adoção coloca no centro das atenções a criança em situação de abandono. Fica privilegiado então o direito da criança a ter uma família, e não mais, como no passado, o interesse do adulto em ter um filho. Além disso, fica evidenciada a relação afetiva como base segura da ligação que se estabelece entre os pais e filhos, além dos laços de sangue.

É preciso reafirmar a necessidade de verificar as relações existentes entre os vários sujeitos do universo da adoção. É preciso superar o consumismo emotivo $e$ liberar a opinião pública da cultura da indiferença. Hoje falta uma coordenação dos esforços e das intenções. Na adoção, cada um tem a sua 'verdade', e cada um é, forçosamente, levado a ler a realidade segundo os próprios parâmetros de avaliação, o que não favorece a integração com outras experiências. $\dot{E}$ como se, numa orquestra, cada músico tivesse uma partitura diferente."

No n. 59, de abril de 1994 o psicólogo João Seabra Diniz, O Afeto, a Lei e a Realidade Social. A Intervenção da Autoridade Judicial, ocupa quatro páginas para demonstrar que um trabalho a realizar no campo da adoção tem que ser 
feito de uma forma pluridisciplinar, já que importa ter igualmente presentes considerações de ordem jurídica, social e psicológica. A solução concreta resultará da compatibilidade destes três tipos de exigências, às quais se juntarão, em certos casos também como decisivos, considerações de ordem médica.

Descreve, pois a adoção como a inserção num ambiente familiar, de forma definitiva e com aquisição de vínculo jurídico próprio da filiação, segundo as normas legais em vigor, de uma criança cujos pais morreram ou são desconhecidos, ou, não sendo este o caso, não querem ou não podem assumir o desempenho de suas funções parentais, ou são pela autoridade competente considerados indignos para tal.

Importa, pois, para que uma situação de adoção possa ser devidamente entendida e trabalhada, distingui-la bem dos outros recursos de proteção à infância, em especial da colocação familiar, com que tantas vezes aparece confundida, mesmo por técnicos que trabalham nesses setores.

\section{(...)}

$\mathrm{Na}$ área das relações interpessoais diretas, além de seus aspectos exteriores observáveis, há uma dimensão da realidade que é de fundamental importância. É a dimensão interior, a realidade psíquica, onde as relações se vivem a partir dos afetos, que podem ser de qualidades várias, por vezes pouco claro, tumultuoso ou mesmo violento, que determina decisivamente como vão decorrer as relações entre pessoas e portanto, dizem de outro modo, o que se pode esperar dessas mesmas relações.

Estamos aqui perante uma situação quase contraditória, que é preciso clarificar bem. Por um lado, é o Direito que vai regular externamente as relações entre as pessoas. A sentença do juiz pode mesmo impor certas soluções dentro das relações familiares. Por outro lado, é do mundo interno dos afetos que vai depender, essencialmente, a qualidade e a evolução dessas mesmas relações.

A tal contradição estaria em que, embora seja o juiz quem "decide" ele não tem, de fato, poder sobre os afetos que, em última análise, são o que vai "decidir" o que realmente irá acontecer. Porque não há nenhuma autoridade neste mundo, nem nenhum argumento lógico, por mais bem construído que seja, que possa impor a uma pessoa que ame outra, embora ela eventualmente possa "ter direito" a esse amor. $E$ isto quer se trate de cônjuges, de filhos ou de pais. Nem mesmo nós próprios podemos decidir se vamos amar uma pessoa ou se vamos deixar de a amar. 
E, para não alongar mais citações, no exemplar n. 72, de junho deste ano de 1995 Laura Maria Ferreira Bueno, Promotora de Justiça e Coordenadora do Centro de Apoio Operacional da Infância e da Juventude, em Goiânia, Os Desafios da Adoção no Brasil demonstra que ali "a preparação se dá através da equipe técnica do Juizado da Infância e da Juventude com a realização de entrevistas individuais e sindicâncias na residência daqueles que pretendem adotar"

Essa análise que a doutrina, a lei, a jurisprudência, o simples bom senso exige, levada a efeito por uma equipe multiprofissional outra coisa não faria senão confirmar as comoventes fotos de fls. 90 e seguintes exibem à evidência: como o bebê está instalado com todo o conforto em seu lar, os cuidados com que é alimentado, tratado, assistido, a acolhida que recebeu dos irmãos, dos tios, dos padrinhos, da própria netinha do adotante.

Que termo de comparação poderia proporcionar a habitação que Levi Teodoro, que se diz técnico em contabilidade, profissão que nunca exerceu e que confessa explicitamente, vive do produto de uma precária pesca que ele mesmo leva aos restaurantes da cidade?

Da manifestação de Levi Teodoro do Prado não resulta explicitamente não ter ele prestado a assistência à gravidez de Elisete, porquanto depois que romperam o relacionamento amoroso, esta já grávida amasiou com outra pessoa por nome de Juliano, sendo que este não aceitava a presença daquele?

Não está declarado que "tem como atividade principal, a de pescador, vendendo sua pesca em bares e mercados desta cidade?"

Seu reconhecimento de que "não resta dúvida que as condições dos adotantes são magníficas, pois está claro, que são privilegiados intelectualmente e economicamente"; de que ele não é rico, sendo que apenas cursou o segundo grau, contudo a diferença intelectual e econômica, que se espelha entre o pai natural e os adotantes, de que "com certeza, Luis Roberto, não terá babás, quarto de luxo, convênio médico, chácara de recreio, automóvel importado, e nem irá residir em condomínio fechado, porquanto as condições de vida do pai natural não permitirá oferecer tantas regalias," não poderiam servir de melhor fundamento para o reconhecimento da necessidade de se abstrair toda decisão relativa a tão-delicada questão da disputa entre os pais de sangue e os pais de devoção, para centralizá-la exclusivamente no interesse do menor.

Revelaria ainda que essa investigação de assistentes sociais e psicólogas que a mãe tem personalidade das mais volúveis, como prova não-só o 
fato de pretender a revogação de ato que consentiu, como o fato de ter convivido durante três meses com o referido Levi, admitido por escrito ter mantido relações sexuais com outros homens no mesmo período e agora estar morando com outro: Juliano.

Revelaria ainda o perigo de entregar uma criança a quem recusou assumir a paternidade quando nasceu, que nunca a viu, e cuja irmã Sonia arrolada como testemunha, nada sabe sobre os fatos, mas foi quem o induziu a proceder por essa forma tão-contrária aos interesses do menor.

4. É o bem-estar, mais que material, espiritual, sua educação, seu futuro da criança que deve prevalecer sobre qualquer outra consideração.

Terceiro quesito "Não é o interesse da criança, seu bem-estar, sua vantagem, a possibilidade de ter acalentada sua infância e formação espiritual num lar bem constituido, que a doutrina moderna e a melhor jurisprudência levam em conta na solução dos casos, de preferência à atenção ao interesse e às pretensões dos pais?"

Tudo se resume em verificar qual será a maior vantagem para a criança: um lar mal-estruturado, visivelmente insuficiente, precário, o do que se inculca sem poder comprovar, ser pai de sangue tão-retardatário no despertar de seu alegado imaginário, fantasioso afeto, ou dos pretendentes à adoção, firme, estável economicamente e socialmente, formado por dois profissionais em carreira superior.

"Vantagem" até lexicamente é lucro, benefício, proveito, ganho.

A intenção será como consignou a Promotora de Justiça Ana Lúcia Mutti de Oliveira Sanseverino, $O$ Estatuto da Criança e do Adolescente. A adoção na nova lei, Justitia, jan/mar. 1991, v. 153, pp. 61-71 - a de que a nova relação familiar venha "a beneficiar o menor com melhores condições de vida, quer no aspecto emocional, quer no aspecto social. Quanto ao aspecto psicológico, é evidente, a criança ou adolescente, necessariamente, deverão estar melhor amparados, e, no tocante ao aspecto social, entendendo que se for possivel deverá trazer para eles melhor proveito; no entanto, não será este o fator que impedirá a adoção. 
Vale dizer, aquele que não dispuser de situação econômica privilegiada não será afastado da viabilidade de realizar sua vontade de adotar".

Externa surpresa no tocante o requisito de fundar-se a adoção em "motivos legítimos"

Considera evidente que ninguém se dispõe a acolher um filho em seu lar, senão por justo motivo, que é procriar. "Procriar pela via indireta, já que a natureza negou a possibilidade da maternidade ou da paternidade, ou ainda, procriar porque percebe ser portador de razoável dose de disponibilidade afetiva que lhe permitirá distribuir e doar amor a mais um filho, encaminhando ao novo lar de maneira diversa. É, portanto, óbvio que tal norma não traduz qualquer facilidade palpável para aquele que pretende adotar, ficando este último exposto a indagações, a respeito, por conta do subjetivismo do serviço social, do serviço de psicologia e do próprio Juiz de Direito que poderá entender, por exemplo, que uma promessa para algum Santo não espelha um motivo legítimo.

A intenção terá sido evitar finalidades especulativas, principalmente o "comércio de crianças para o exterior"

Não impõe a Convenção sobre os Direitos da Criança, subscrita em Nova York, em data de 26 de janeiro de 1990, na sede da ONU, que entrou em vigor internacional em 2 de setembro de 1990, ratificada pelo Governo brasileiro aos 24 do mesmo mês e baixada por Decreto n. 99.710, de 21 de novembro de 1990, com força, portanto, de lei interna, transcrita às pp. 33-36, em seus tópicos essenciais, em nosso Estatuto da Criança e do Adolescente: art. $3^{\circ}$, inciso I:

"Todas as ações relativas às crianças, levadas a efeito por instituições públicas ou privadas de bem-estar social, tribunais, autoridades administrativas ou órgãos legislativos, devem considerar primordialmente, o interesse maior da criança?"

Não determina, por sua vez, o referido Estatuto, nessa mesma linha, art. 43, que a adoção somente seja deferida "quando apresentar reais vantagens para o adotando..." Todas essas proposições apontam não escapou a Osvaldo Palotti Junior, Juiz de Direito e Dircéia Moreira, advogada e professora de Direito do Menor da Universidade Estadual de Ponta Grossa, PR. 
O Estágio de Convivência e a Preparação de Casais para Adoção (Tribuna da Magistratura, São Paulo, março de 1993, p. 04 ):

"para a necessidade de a autoridade judiciária buscar sempre a melhor família que puder encontrar para a criança em condições de adoção."

Bem que merecia ser aqui transcrita longa reportagem da edição de 25 de agosto de 1993 da revista Veja: "O direito de escolher. Menina americana trocada na maternidade é autorizada a romper todos os laços com os pais verdadeiros", relatando o que aconteceu com Kimberly Mays: "um dos mais sombrios pesadelos que atormentam a mente das crianças, fazem a festa dos autores de novelas e deixam o resto do público diante do tipo de situação que se vê no programa 'Você Decide'."

Refere outra "novela" que, de todo em todo semelhante ao caso da consulta, começou em fevereiro de 1991, quando a operária Cara Clausen, 28 anos, deu à luz uma menina, fruto de um romance passageiro com o caminhoneiro Dan Schimidt. Solteira e pobre, Cara entregou a criança para adoção, logo depois do parto. Roberta DeBoer, uma dona de casa estéril que tentava há dois anos adotar uma criança, soube do bebê e viajou de Michigan, onde morava com o marido, Jan, para o Estado de Iowa, ao encontro de Cara. O casal acertou a adoção, assinou os papéis todos e levou a menina para casa. Acontece que Cara se arrependeu. Logo ao sair do hospital, procurou o ex-namorado (que nem sabia que era pai) e pediu a criança de volta. Como havia registrado o bebê em nome de outro namorado, Cara tinha em suas mãos um forte argumento para anular a adoção: o pai verdadeiro, Dan, não havia assinado os papéis dando o consentimento.

O casal DeBoer resolveu lutar com todas as forças pela posse da menina. Enquanto o caso rolava de tribunal em tribunal, passaram-se mais de dois anos. Cara e o caminhoneiro Dan Schimidt se casaram, Jessica foi crescendo e os laços entre a criança e os pais adotivos se estreitaram. Jan e Roberta DeBoer levaram o caso à imprensa e conquistaram a opinião pública americana. Às vésperas da decisão final, uma pesquisa mostrou que $78 \%$ dos entrevistados achavam que Jessica deveria ficar com os pais adotivos, que tinham situação financeira confortável.

Mas a Justiça lhes negou a custódia. No dia 2 de agosto passado, Jessica foi entregue ao casal Schimidt. A mãe adotiva estava em prantos. A menina 
também chorava. "Quero meu pai, onde está meu pai?", balbuciava Jessica, que nem mesmo continuará a se chamar assim. Seu novo nome é Anna Clausem Schimidt.

(...)

Os dilemas éticos são cada vez mais cabeludos. Quem tem mais direito, os pais adotivos ou os naturais? Pai é quem gera ou quem cria?

Deve-se pensar no bem-estar da criança ou ceder ao direito de sangue, tão-poderoso, dos pais biológicos? $O$ drama de Jéssica espalhou pânico entre os casais que adotaram crianças nos Estados Unidos. "Os pais adotivos estão apavorados, telefonam perguntando se fizeram tudo certo na hora da adoção", observa Susan Freivalds, diretora do Grupo Famílias Adotivas da América.

Num outro caso, que não transcreveríamos se não forçados pela necessidade de insistir na indispensabilidade dos exames minuciosos que só as assistentes sociais terão lugar, tempo, paciência e diga-se mesmo, competência para conduzir, deixa patente que o veredito da Justiça nem sempre se revela tão-acertado como a sentença de Salomão no Velho Testamento. Joseph Wallace, um menino de três anos, passou boa parte de sua vida em orfanatos enquanto a mãe, Amanda, vivia internada em hospitais psiquiátricos. Numa das vezes em que teve alta, Amanda foi a um tribunal para pedir a guarda do garoto.

"Quero dar-lhe amor, afeto, tudo o que não tive", implorou.

Os juízes se condoeram e entregaram-lhe a criança em fevereiro daquele ano. Passados dois meses, Amanda foi presa. Tinha enforcado o próprio filho com um fio elétrico.

E para encerrar, o caso de Maya, relatado por Marcos Sá Corrêa, à p. 29, que vinha de Santa Catarina "embrulhada em documentos falsificados por contrabandistas de bebês e iria para Israel com a mãe adotiva Sapirit Friedmann.

Salva pela polícia, Maya passou a ser ameaçada pela lei. Seu futuro está espetado num processo que decidirá se ela deve crescer numa família com renda anual de 200 mil dólares ou numa sociedade que lhe oferece, em média, 100 vezes menos. Num caso, terá 8,5 milhões de quilômetros quadrados de amplidão e o aperto de serviço público superpovoados - uma cama de hospital para 313 brasileiros, por exemplo. No outro, viverá entre 22 mil quilômetros quadrados de horizontes, mas com o dobro de folga para internação.

Maya fez um mês, mas já aposta numa disputa judicial com onze anos de vida. Em Israel, a expectativa de longevidade para a mulher chega a 79 anos. Aqui, a 68. E pode acabar na orfandade por excesso de pais: o biológico, que sumiu, 
o ginecologista israelense David Friedmann, que contratou dois advogados para brigar pela adoção, e o delegado Eleotério Parracho, que se candidatou à vaga pela imprensa. $O$ país em que Maya nasceu às vezes parece doido por crianças.

Tem para elas um estatuto ciumento, que regula a adoção por estrangeiros como se fosse reserva de mercado. E conta com juízes de menores nacionalistas, como o carioca Liborni Siqueira, que esticou as restrições legais até o limite do desencorajamento. Antes de levar legalmente um aprendiz de brasileiro para o exterior, em sua jurisdição, o pretendente deve conviver com ele no mínimo por sessenta dias. No estatuto, o prazo é de quinze dias.

Pior para Sapirit, a mãe adotiva. Ela viajou para um Brasil exportador de crianças e desembarcou em outro onde infância é assunto sério. Sapirit permaneceu por semanas num cárcere feminino em Niterói, apesar do atestado de boas intenções que lhe passou a polícia: seus documentos "sobre a habilitação legal para adoção em país estrangeiro, elaborados em Israel" anexados ao inquérito. Sapirit é uma ex-modelo famosa em Israel. Não podendo ter filhos, cria um menino de três anos e quer outra criança.

Teve oportunidade a vibrante jornalista Eunice Nunes, entre muitos outros escritos, de encarecer, em artigo publicado na Folha de S. Paulo, de 26 de fevereiro último, p. 4-2, Processos de Adoção devem ser considerados fatores humanos, de encarecer que o desfecho de um pedido de adoção, como de qualquer outro processo judicial, depende de como o juiz interpreta a lei e analisa os fatos que são submetidos à sua apreciação. É por isso que casos aparentemente semelhantes podem ter finais muito diferentes, dependendo de quem julga o caso.

Para o juiz do Primeiro Tribunal de Alçada Civil, Ademir de Carvalho Benedito, no campo da adoção, o Estado na figura do juiz tem muito poder. Por causa disso e por se tratar de uma questão com forte componente humano, Benedito defende um tratamento psicológico para os juizes que atuam na área.

A adoção é irrevogável. Ela confere a condição de filho ao adotado, com os mesmos direitos e deveres dos filhos naturais, inclusive sucessórios, desvinculando-o dos pais biológicos.

Para uma adoção bem-sucedida, em primeiro lugar, os pais biológicos da criança devem ser destituídos do pátrio poder. "Depois, deve levar-se em conta a vinculação afetiva entre adotantes e adotados, assim como a integração deste na nova família" afirma a psicanalista Eliane Marracini, do Instituto de Estudos Interdisciplinares de Direito de Familia (IEIDF). 


\section{(...)}

Antes da adoção, o juiz estabelece um estágio de convivência que, em média, dura um ano. $O$ estágio pode ser dispensado se a criança tiver menos de um ano ou se já tiver com a adotante há tempo suficiente para se poder avaliar a constituição do vínculo.

"O vínculo afetivo com os pais psicológicos, o mais importante, deve ser preservado", diz a psicanalista Maria Antonieta Motta.

5 - Da sentença (na verdade, despacho) que denega adoção, cabe recursos de embargos. Seus efeitos para que não sejam desastrosos - têm que ser não-só translativos, mas também suspensivos.

Quarto quesito. "Qual o recurso cabivel da sentença? Quais os efeitos do recurso?"

A resposta nô-la dá o art. 198 do Estatuto da Criança e do Adolescente, art. 198, ao adotar o sistema recursal do Código de Processo Civil aprovado pela Lei n. 5.869 de 11 de janeiro de 1973 e suas alterações, com as adaptações que o aludido dispositivo discrimina em oito itens.

Lembra Tânia da Silva Pereira, A adoção no Brasil, já invocada, p. 421:

"A sentença de Adoção é constituída e dá nascimento a um novo estado civil do adotado. Desta sentença cabe Apelação a qual deverá ser interposta no prazo de 10 dias independentemente de preparo (art. 198, I e II)".

Apenas do despacho denegatório de apelação é que cabe o agravo de instrumento, configurado erro inescusável a interposição de correição parcial, impedindo a incidência do princípio da fungibilidade recursal, demonstramos às pp. 620-621 de nosso referido Comentários ao Estatuto da Criança e do Adolescente p. 620, invocando acórdão da Câmara Especial do TJSP, de 08 de agosto de 1991, Correição Parcial n. 13.224, RT 671/83, rel. Des. Marino Falcão.

Diagnosticamos, à p. 36 o vício histórico das nossas Constituições anteriores: não consagrar um direito da criança independente do pai e da mãe, e sim incorporado de tal forma que só possa ser exercido através deles. E transcrevemos considerar espantoso o deputado Nelson Aguiar, em discurso que citamos que em 
nenhuma delas preocupou-se o legislador constituinte em estabelecer os princípios do direito da criança no texto das mesmas, como já fizeram todas as nações do mundo.

O Brasil nisso negligenciou, mesmo após o advento da Declaração Universal dos Direitos da Criança, de 20 de novembro de 1959, de que somos também signatários.

Liborni Siqueira, conhecido juiz e respeitado sociólogo incluíra em seu "Anteprojeto de Adoção", um

Art. 7. "Efetivada a adoção, com observância das formalidades legais, não é permitida a investigação de paternidade ou a reclamação dos pais ou responsáveis que tenham praticado o abandono do menor, ou contribuído para sua situação irregular"

Os efeitos devem ser não-só translativo, como também suspensivo, sob pena de tornar-se irremediável uma iniqüidade eventualmente perpetrada com boaintenção.

É tempo de encerrarmos.

E não poderíamos encontrar melhor fecho do que transcrever memorável acórdão da $2^{\mathrm{a}}$ Câmara Cível do Tribunal de Justiça do Rio de Janeiro, registrado em 26 de agosto de 1994 de que foi relator o Des. Decio Xavier, Adv. n. 69.139 considerando inaceitável o entendimento de que a adoção é instituto supérfluo, fruto de desconhecimento da verdadeira finalidade da adoção. Muito menos tem a adoção o sentido de proteger criaturas desvalidas e abandonadas. $A$ adoção advém da busca de fazer uma criança integrar uma família e de se completar a família com uma criança. Difícil é saber quem recebe e quem mais se doa no dia em que se realiza a adoção, tal é o mútuo benefício que sobressai dessa transformação maravilhosa, elevada e cheia de amor, que se opera na vida dos adotantes e adotado.

São Paulo, julho de 1995. 